
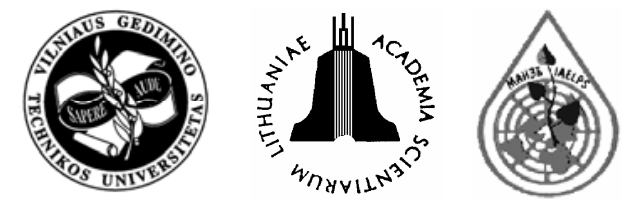

\title{
INDUCED PROTEIN PROFILE CHANGES IN ARSENATE TOLERANT AND SENSITIVE PSEUDOMONAS FLUORESCENS STRAINS
}

\author{
Stefan Shilev ${ }^{1}$, Almudena Fernández López ${ }^{2}$, María Sancho Prieto ${ }^{3}$, Enrique David Sancho Puebla ${ }^{4}$ \\ ${ }^{1,2,3,4}$ Dept of Microbiology, Edif. Severo Ochoa, Campus de Rabanales, University of Córdoba, \\ 14071-Córdoba, Spain.E-mail: ${ }^{4}$ edsancho@uco.es \\ ${ }^{1}$ Dept of Microbiology and Environmental Biotechnologies, Agricultural University-Plovdiv, \\ 12, Mendeleev St, 4000-Plovdiv, Bulgaria. E-mail: ${ }^{1}$ stefan.shilev@au-plovdiv.bg
}

Submitted 15 May 2007; accepted 04 Oct. 2007

\begin{abstract}
Pseudomonas fluorescens are gram-negative, motile, rod-shaped bacteria known for their metabolic versatility. Many strains of this species possess excellent capability to colonize plant roots, promoting plant growth in soils contaminated with toxic metals. P. fluorescens biotype $\mathrm{F}$ is a strain tolerant to arsenic which had been isolated previously from soil contaminated with arsenic and other toxic metals and characterized as a promoter of plant growth and accumulation of arsenic. In the present work we studied the protein profile of this strain together with the profile of a sensitive $P$. fluorescens CECT 378 in the presence and absence of sodium arsenate using two-dimensional polyacrylamide gel electrophoresis (2D-PAGE). The gels were analyzed by PDQuest, while the statistical significance was proved by ANOVA. We found 9 differentially expressed proteins in the tolerant strain -4 new proteins, 4 upregulated proteins and 1 downregulated proteins in the presence of $1000 \mathrm{ppm}$ As. In the non-tolerant strain there were 7 differentially expressed proteins -1 new protein, 3 upregulated proteins and 3 downregulated proteins. The identification of the proteins with MALDI-TOF is in progress.
\end{abstract}

Keywords: arsenic, Pseudomonas fluorescens, tolerance, proteins, 2D-electrophoresis, rhizobacteria.

\section{Introduction}

The fluorescent pseudomonads are known as a wide group of gram-negative, non-spore forming, motile, rodshaped bacteria with an important metabolic versatility and pathogenicity [1]. Many strains of genus Pseudomonas possess the capability to promote plant growth when develop in the rhizosphere [2, 3], due to their 1aminocyclopropane-1-carboxylate (ACC) deaminase activity, indoleacetic acid (IAA) and siderophore production [4]. Plant growth-promoting bacteria (PGPR) that contain ACC deaminase may act to insure that the ethylene level does not impair root growth [5]. By facilitating the formation of longer roots, these bacteria may enhance seedling survival and plant root growth. The adaptation capabilities of both partners of the associative symbiosis: plant and associate bacteria, as well as the bioremediation potential of the microsymbiont are of importance in minimizing the detrimental effect of heavy-metal pollution. On the other hand, PGPR could improve host plant growth and development in heavy metal-contaminated soils by mitigating toxic effects $[6,7]$ and/or enhance plant accumulation of these metals into the plant tissues $[8,9]$. All these positive effects improve the plant growth and accumulation of metals when develop in heavy metal-contaminated soils.

Among the PGPR, Pseudomonas fluorescens disposes of an efficient system for survival in high abiotic stress conditions produced by metals and metalloids [10]. The monitoring of sensitivity/tolerance of these microorganisms has a primary importance in preparation of inocula for bioremediation of heavy metal-contaminated soils. Although some metals $(\mathrm{Cu}, \mathrm{Zn})$ are considered as essential and play an important role in maintaining the biochemical activity, a huge number of them are toxic even in very small concentrations. Microorganisms, and the bacteria in particular, have developed different tools to protect themselves by the oxidative stress produced by the metals. Usually this is expressed in detoxification mechanisms, including compartmentalization, binding, efflux, etc. [10] in tolerant strains. In the opposite, the hydroxide radicals formed in redox reactions of heavy metals are highly reactive molecules and play a role in a number of deleterious reactions, such as peroxidation of lipids which conducts to membrane disruption and oxidation of proteins, causing their inactivation. This can lead to alteration in structure or function of these molecules. To understand the function of genes in an organism, it is not only required to know which genes are expressed, when and where, but also, what protein end products are and under which conditions they accumulate in certain tissues. There are large numbers of specific proteins reported in various genera of bacteria that showed increase in their level of expression, upon adverse conditions, such as heat, toxic elements and nutrient limitations. In post- 
genomic investigations, proteomics is one of the best strategies used to reveal the dynamic expressions of whole proteins in cells and their interactions. The term proteome is used here to describe the complex state of an organism under defined conditions. Due to its high resolution, two-dimensional PAGE, combined with a high throughput mass spectrometry and bioinformatics, is widely used for protein separation and identification, which is considered sufficiently discriminating to allow a unique identification of unknown proteins [11]. Also, the identification of differentially expressed proteins could clarify the gene response to some physiological actions and environmental conditions.

As a response to the exposure to four amino acids (Asn, Asp, Gln and Glu) as different carbon and nitrogen sources, P. fluorescens ATCC 13525 and P. putida KT2440 coordinately expressed a well-defined set of genes, leading to induction of the same proteins in both strains [12].

Sharma et al., 2006, demonstrated [13], that the exposure of $P$. fluorescencs ATCC 948 to three different heavy metals separately resulted, in differential expression of cellular proteins, but also in disappearance of the fluorescence, the basic characteristic shown by the fluorescent Pseudomonas, indicating the action of the metals on global regulatory components, controlling the siderophore molecules imparting this bacterial quality.

The aim of the work was to study protein profile changes and differentially expressed proteins in Pseudomonas fluorescens biotype $\mathrm{F}$ and Pseudomonas fluorescens CECT 378, exposed to sodium arsenate as one of the most frequent soil contaminants.

\section{Materials and methods}

Acrylamide ( $N, N$-methylene bis acrylamide), carrier ampholytes, immobilized $\mathrm{pH}$ gradient (IPG) strips and mineral oil were purchased from Bio-Rad Laboratories; Coomassie brilliant blue G250, 1,4-dithiothreitol (DTT), 2-iodoacetamide and ammonium persulfate - Merck Darmstadt, Germany; Bradford reagent, thiourea, Ttris, 3-[(3-cholamidopropyl) dimetyl-ammonio]-1-propanesulfonate (CHAPS) and glycine - Sigma Chemie.

\subsection{Strains and growth conditions}

Two strains were used in this study, Pseudomonas fluorescens biotype $\mathrm{F}$, isolated from metal-contaminated soils of Aznalcóllar (Southern Spain), and Pseudomonas fluorescens CECT 378 obtained from The Spanish Type Culture Collection. It should be mentioned that the second strain corresponds to the strain P. fluorescens ATCC 13525 (Collection of Rockville, Maryland, USA). The first one had been characterized as a strain tolerant to arsenic (arsenate and arsenite) [7], while the second one was found to be sensitive to this metalloid. Both cultures were maintained as slants in Pseudomonas PHAGE agar medium at $4{ }^{\circ} \mathrm{C}$, while the experimental growth was carried out in a liquid medium at $28^{\circ} \mathrm{C}$ with the presence or absence of $1000 \mathrm{ppm}$ of arsenic as sodium arsenate $\left(\mathrm{Na}_{2} \mathrm{HAsO}_{4}\right)$ till reaching O.D. $=0.5(550 \mathrm{~nm})$. The cells were then harvested by centrifugation at $5000 \mathrm{rpm}$ for $15 \mathrm{~min}$.

\subsection{Preparation of cell extracts}

The pellets were re-suspended and washed, first in $0.02 \mathrm{M} \mathrm{MgCl}_{2}$, and after that - in deionized water. Each time the cells were obtained by centrifugation at $6000 \mathrm{rpm}, 4{ }^{\circ} \mathrm{C}$ for $15 \mathrm{~min}$. The pellets were resuspended in $500 \mu$ lysis buffer (thiourea $2 \mathrm{M}$, urea $7 \mathrm{M}$, CHAPS $4 \%$, DTT $1 \%$ and carrier ampholytes $2 \%$ ), followed by repeated ultra-sonication with intervals in ice. Finally, the extracts were centrifuged at $12000 \mathrm{rpm}$, $4{ }^{\circ} \mathrm{C}, 15 \mathrm{~min}$., and the supernatants were stored at $-20^{\circ} \mathrm{C}$.

\subsection{Isoelectric focussing (IEF)}

The protein quantification in each extract was made by the Bradford method (Bio-Rad) using bovine serum albumin as a standard. Protein sample (adjusted protein concentration of $1 \mu \mathrm{g} \mu^{-1}$ ) of $400 \mu \mathrm{l}$ was loaded on a $17 \mathrm{~cm}$ IPG strip pH 4-7. Mineral oil covered the strip to avoid evaporation of the protein sample. IEF was performed in focusing tray using the following conditions: i) rehydration active for $12 \mathrm{~h}$; ii) $500 \mathrm{~V}$ linear current for $1 \mathrm{~h}$; iii) $1000 \mathrm{~V}$ linear current for $1 \mathrm{~h}$; iv) complete focusing was made applying $8000 \mathrm{~V}$ linear current for $8 \mathrm{~h}$.

\subsection{SDS-PAGE}

The strips were equilibrated using DTT and iodoacetamide equilibration buffers for $15 \mathrm{~min}$. and kept on the stacking gel at $13 \%$ and sealed with $0.5 \%$ agarose with bromophenolblue. SDS-PAGE was performed using Protean IX system of BIO-RAD. The current was first adjusted at $30 \mathrm{~mA} / \mathrm{gel}(60 \mathrm{~min}$.), then at $60 \mathrm{~mA} / \mathrm{gel}$ till the end. All the experiments were repeated three times. Gels were stained with recently made $1 \%$ Coomassie Brilliant Blue G250 to visualize the proteins [14] in $20 \%$ methanol. Posteriori, they were treated with Tris- $\mathrm{H}_{3} \mathrm{PO}_{4}$, methanol and ammonium sulfate and water clarified.

\subsection{Analysis}

The gels were scanned and analyzed using PD-Quest software Version 7.1.0 (Bio-Rad). Spot quantity was defined as the sum of the pixel values comprising proteins spots subtracting the sum of background pixel values. Finest, small and large spot clusters were marked and the horizontal and vertical streaking was removed. The image of protein profile of the cells of both strains grown without arsenate was taken for control and compared with the profile of those grown in 1000 ppm of arsenic. Differentially expressed and new proteins were marked and analyzed on the basis of a set of three independent pairs of gels. The differences between selected spots in control and arsenic treatments were considered to be significant by ANOVA $(p<0.05)$ using the softwear Statistix 8.0. 


\section{Results}

Both strains, $P$. fluorescens biotype $\mathrm{F}$ and $P$. fluorescens CECT 378, were grown in Pseudomonas PHAGE medium with or without arsenic till reaching the medium stationary phase. The pattern of protein separation expressed using two-dimensional PAGE was consistent in all the gels (Fig 1). Comparing the treatment for each strain with its corresponding control, the appearance of the total of 9 differentially expressed and statistically significant protein spots in $P$. fluorescens biotype $\mathrm{F}$ and 7 spots - in P. fluorescens CECT 378 was observed after exposure to $1000 \mathrm{ppm}$ of arsenic.
From them, in the tolerant strain in the presence of metalloid 4 new, 4 upregulated and 1 downregulated spots, comparing with the corresponding control (Fig 1A), were found.

On the other hand, from the 7 differentially expressed spots in the non-tolerant strain, 1 spot was new, 3 spots - upregulated and 3 spots - downregulated (Fig 1B). Tables 1 and 2 summarize the weight, the isoelectric point and the trend of each of these proteins under experimental conditions (in the presence of arsenate).

A

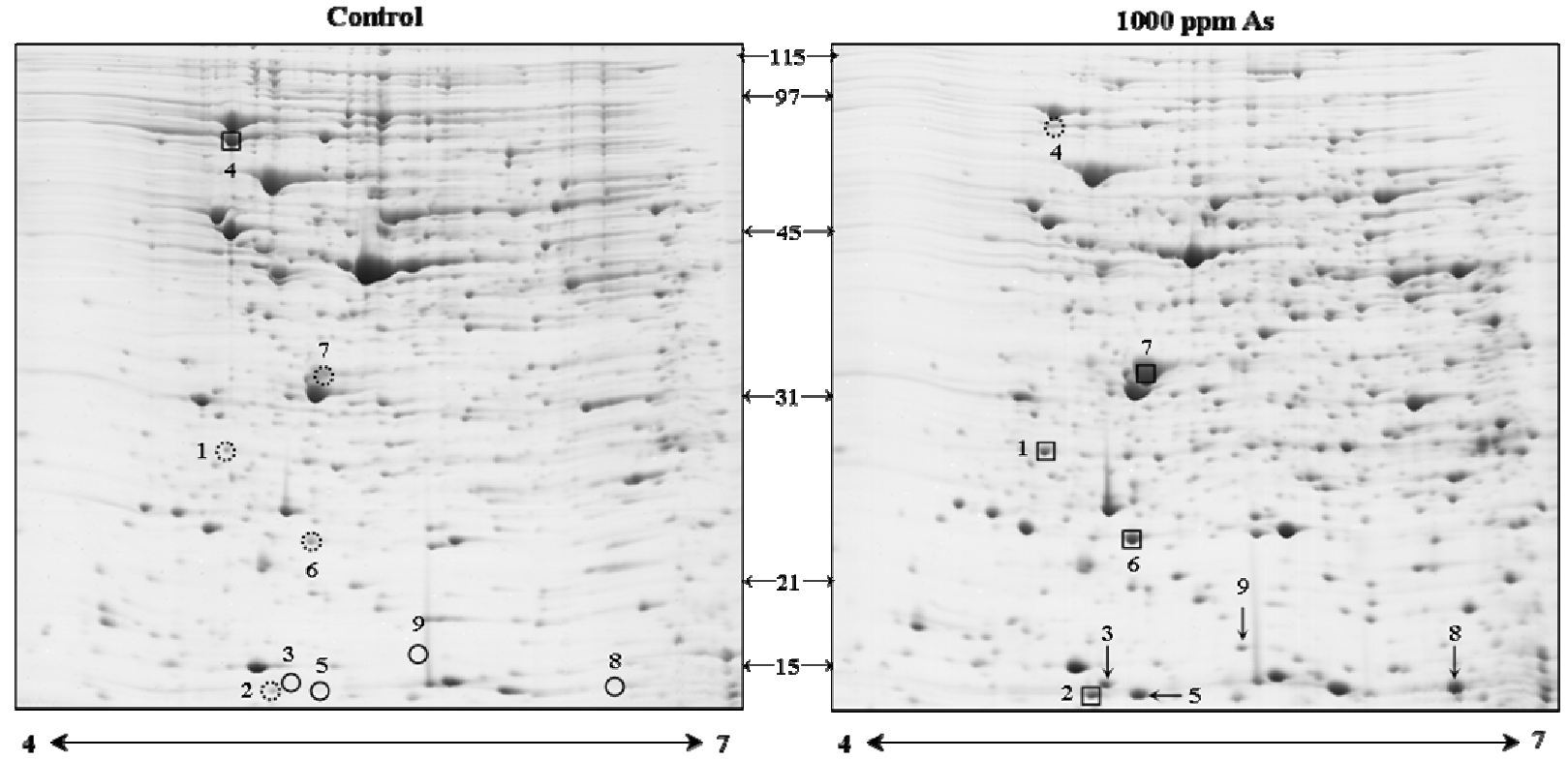

B Control

$1000 \mathrm{ppm}$ As

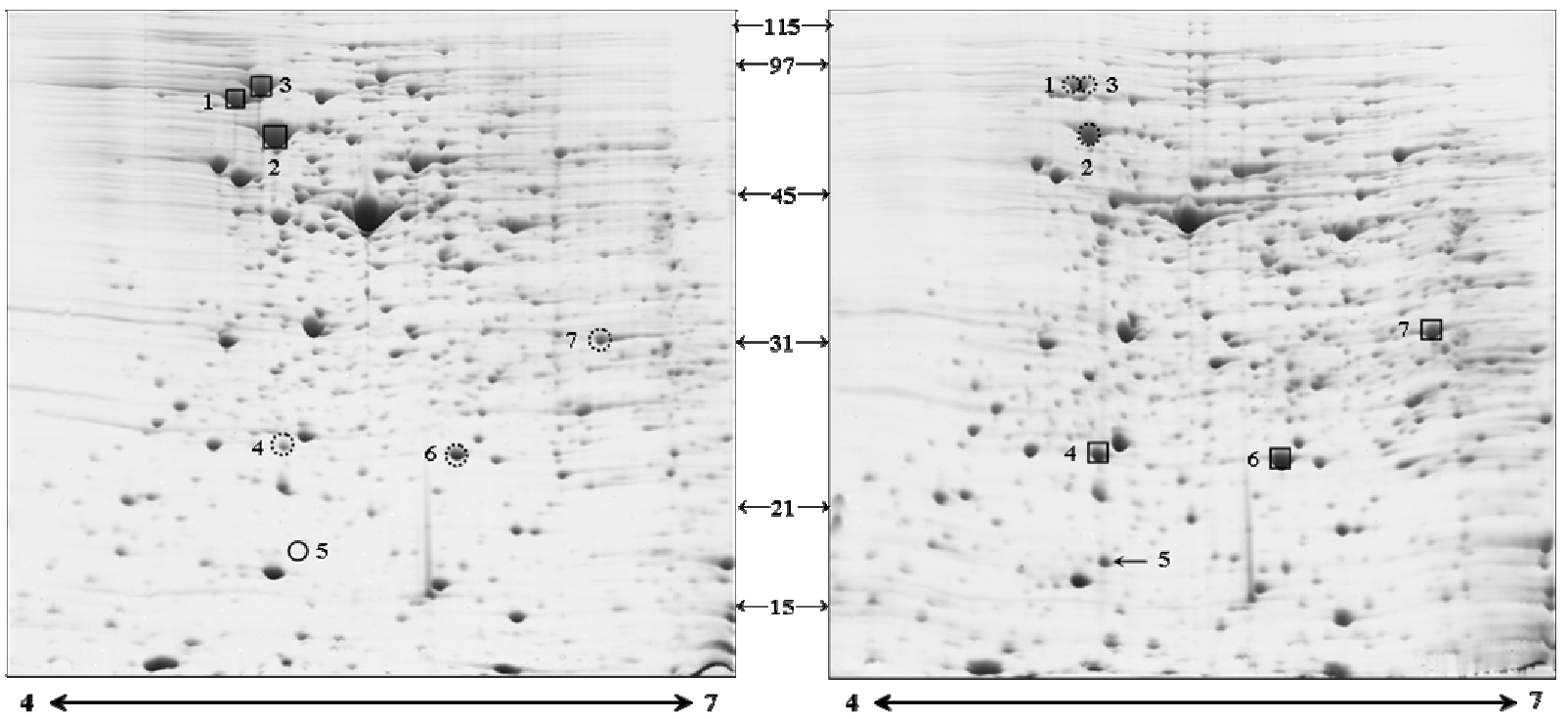

Fig 1. 2D profile of Pseudomonas fluorescens biotype F (A) and Pseudomonas fluorescens CECT 378 (B) presenting the differentially expressed proteins in the presence or absence (control) of $1000 \mathrm{ppm}$ of arsenic. The values of the weight standards are situated between the gels. Major protein spots upregulated in each case are marked by squares, while the downregulated ones are marked by a circle of dots. The absence of proteins is indicated by a circle of a solid line, while the new proteins - by an arrow. The numbers show the relative position of the differentially expressed spots described in Tables 1 and 2 
Table 1. Description of differentially expressed proteins in the cells of $P$. fluorescens biotype $\mathrm{F}$

\begin{tabular}{cccc}
\hline $\begin{array}{c}\text { Spot } \\
\text { No. }\end{array}$ & $M W$ pred. & $p I$ pred. & $\begin{array}{c}\text { Trend under experimental } \\
\text { conditions }\end{array}$ \\
\hline 1 & 27.58 & 5.0 & Upregulated \\
2 & 14.4 & 5.18 & Upregulated \\
3 & 14.93 & 5.23 & Only in arsenate \\
4 & 63.94 & 5.03 & Downregulated \\
5 & 14.41 & 5.35 & Only in arsenate \\
6 & 23.16 & 5.33 & Upregulated \\
7 & 32.15 & 5.38 & Upregulated \\
8 & 14.73 & 6.55 & Only in arsenate \\
9 & 16.9 & 5.7 & Only in arsenate \\
\hline
\end{tabular}

Table 2. Description of the differentially expressed proteins in the cells of $P$. fluorescens CECT 378

\begin{tabular}{cccc}
\hline $\begin{array}{c}\text { Spot } \\
\text { No. }\end{array}$ & $M W$ pred. & $p I$ pred. & $\begin{array}{c}\text { Trend under experimental } \\
\text { conditions }\end{array}$ \\
\hline 1 & 62.46 & 5 & Downregulated \\
2 & 51.20 & 5.13 & Downregulated \\
3 & 66.20 & 5.09 & Downregulated \\
4 & 23.69 & 5.18 & Upregulated \\
5 & 17.26 & 5.21 & Only in arsenate \\
6 & 23.21 & 5.83 & Upregulated \\
7 & 30.26 & 6.36 & Upregulated \\
\hline
\end{tabular}

\section{Discussion}

In this study we show that the exposure to $1000 \mathrm{ppm}$ of arsenic as sodium arsenate resulted in changes in protein profile in tolerant $P$. fluorescens biotype $\mathrm{F}$ and nontolerant $P$. fluorescens CECT 378. Arsenic modified quantitatively and qualitatively the protein profile of both strains. This was manifested through appearance and mass quantity changes of protein spots in both strains.

Arsenic is not an essential element for cells and could cause toxic (oxidative) effects. The microbial cells under oxidative stress conditions present different dysfunctions due to the lesions caused by reactive oxygen species to DNA, proteins or lipids [15]. It is suggested that metal induced oxidative stress in cells is partially responsible for the toxic effects [16]. Nevertheless, these effects lead to induction of outer membrane protein in $P$. aeruginosa [17] or, generally, to alteration of membrane permeability [18].

In previous studies we reported [9] that $P$. fluorescens biotype $\mathrm{F}$ is a PGPR with potential use in phytoremediation practices, improving plant growth in contaminated soils and increasing arsenic accumulation in plant tissues. This bacteria possesses high tolerance to arsenic (arsenate and arsenite) growing in media supplemented with the metalloid. Moreover, we found that the capacity to grow under these abiotic stress conditions is due to the ability of the bacteria to regulate its internal concentration through sophisticated efflux pumps [19]. It is possible that this protein only appeared or was upregulated under stress conditions provoked by arsenate. Presently we are analyzing in detail the differentially expressed proteins in both $P$. fluorescens strains.

\section{Conclusions}

None of the Pseudomonas fluorescens strains showed statistically important changes when grown under arsenic stress conditions. The tolerant strain $P$. fluorescens biotype $\mathrm{F}$ synthesized 4 new proteins, 4 proteins were upregulated and only 1 protein was downregulated, to survive the oxidative stress. In the sensitive strain $(P$. fluorescens CECT 378), 1 new spot appeared, 3 proteins were upregulated and 4 proteins showed downregulation.

Probably, the identification of protein sequence will reveal the intimate role that each protein realizes in the cell.

\section{Acknowledgments}

We express our gratitude to the Spanish Agency for International Cooperation (AECI) for the post-doc fellowship awarded to Dr. Stefan Shilev, which permitted to realize this work.

\section{References}

1. PALLERONI, N. J. FAMILY, I. Pseudomonadaceae. In Krieg, N. R. and Holt, J. G. (eds.). Bergey's manual of systematic bacteriology. Vol. 1. Williams \& Wilkins. Baltimore. US, 1984, p 141-199.

2. BLOEMBERG, G. V.; LUGTENBERG, B. J. Molecular basis of plant growth promotion and biocontrol by rhizobacteria. Curr Opin Plant Biol, 2001, 4, p 343-350.

3. GLICK, B. R.; KARATUROVIC, D. M.; NEWELL, P. C. A novel procedure for rapid isolation of plant growth promoting pseudomonads. Can. J. Microbiol, 1995, 41, p 533-536.

4. CROWLEY, D. E.; WANG, Y. C.; REID, C. P. P.; SZANSISZLO, P. J. Mechanism of iron acquisition from siderophores by microorganisms and plants. Plant Soil, 1991, 130, p 179-198.

5. GLICK, B. R.; PENROSE, D. M.; LI, J. P. A model for the lowering of plant ethylene concentrations by plant growth-promoting bacteria. J. Theor. Biol., 1998, 190, p 63-68.

6. BELIMOV, A. A.; HONTZEAS, N.; SAFRONOVA, V. I.; DEMCHINSKAYA, S. V.; PILUZZA, G.; BULLITTA, S.; GLICK, B. R. Cadmium-tolerant plant growth-promoting bacteria associated with the roots of Indian mustard (Brassica juncea L. Czern.). Soil Biol. Biochem., 2005, 37, p 241-250.

7. SHILEV, S.; RUSO, J.; PUIG, A.; BENLLOCH, M.; JORRIN, J.; SANCHO, E. D. Rhizospheric bacteria promote sunflower (Helianthus annuus L.) plant growth and tolerance to heavy metals. Minerva Biotecnologica, 2001, 13, p 37-39.

8. SALT, D. E.; BLAYLOCK, M.; KUMAR, N. P. B. A.; DUSHENKOV, V.; ENSLEY, B. D.; CHET, I.; RASKIN, I. Phytoremediation: a novel strategy for the removal of toxic metals from the environment using plants. Biol. Technol., 1995, 13, p 468-474.

9. SHILEV, S.; BENLlOCH, M.; SANCHO, E. D. Pseudomonas fluorescens promotes water and arsenic transport to shoots in sunflower (Helianthus annuus L.) plants. In Risk assessment and sustainable land management using plants in trace element-contained soils. Mench M. and B. 
Mocquot (eds). COST Action 837, $4^{\text {th }}$ WG2, Workshop, Bordeaux, France, 2003, p 43-45.

10. FRANCIS, A. J. Bioremediation of radionuclides and toxic metal contaminated soils and waters. In Bioremediation of metal contaminated soils. Adriano, D. C.; Bollag, J.-M.; Frankenberger, Jr. W. T.; Sims, R. C. (eds.). Am. Soc. Agronom. WI. US, 1999. 7 p.

11. SHEN, S. H.; MATSUBAE, M. \& TAKAO, T. A proteomic analysis of leaf sheaths from rice. Journal of Biochemistry, 2002, 132, p 613-620.

12. SONAWANE, A.; KLÖPNER, U.; HÖVEL, S.; VÖLKER, U.; RÖHM, K.-H. Identification of Pseudomonas proteins co-ordinately induced by acidic amino acids and their amides: a two-dimensional electrophoresis study. Microbiology, 2003, 149, p 2909-2918.

13. SHARMA, S.; SUNDARAM, C. S.; LUTHRA, P. M.; SINGH, Y.; SIRDESHMUKH, R.; GADE, W. N. Role of proteins in resistance mechanisms of Pseudomonas fluorescens against heavy metal-induced stress with proteomic approach. J Biotechnol., 2006, 126, p 374-382.

14. MATHESIUS, U.; KEIJZERS, G.; NATERA, S. H. A.; ROLFE, B. G. Establishment of a root proteome reference map for the model legume Medicago truncatula using the expressed sequence tag database for peptide mass fingerprinting. Proteomics, 2000, 1, p 1424-1440.

15. AVERY, S. V. Metal toxicity in yeasts and the role of oxidative stress. Adv. Appl. Microbiol., 2001, 49, p 111142.

16. SHANMUGANATHAN, A.; AVERY, S. V.; WILLETTS, S. A.; HOUGHTON, J. E. Copper-induced oxidative stress in Saccharomyces cerevisiae targets enzymes of the glycolytic pathway. FEBS Lett., 2004, 556, p 253-259.

17. SAID, A. A.; LIVERMORE, D. M.; WILLIAMS, R. J. Expression of $\mathrm{H} 1$ outer-membrane protein of Pseudomonas aeruginosa in relation to sensitivity to EDTA and polymyxin. Br. J. Med. Microbiol., 1987, 24, p 267-274.

18. DI MODUGNO, E.; ERBETTI, I.; FERRARI, L.; GALASSI, G.; HAMMOND, S. M.; XERRI, L. In vitro activity of the tribactam GV104326 against gram-positive, gram-negative, and anaerobic bacteria. Antimicrob. Agents Chemother., 1994, 38, p 2362-2368.

\title{
PROTEINO PROFILIO PAKEITIMAI, SUKELTI ARSENĄ TOLERUOJANČIOJE IR JAUTRIOSE PSEUDOMONAS FLUORESCENS ATMAINOSE
}

\author{
S. Shilev, A. F. López, M. S. Prieto, E. D. S. Puebla \\ Santrauka \\ Pseudomonas fluorescens yra gramneigiama, judanti lazdelès formos bakterija, žinomas jos metabolinis universalumas. \\ Daugelis šios rūšies atmainų gerai sugeba kolonizuotis augalų šaknyse ir padeda augti augalams toksiniais metalais užterš- \\ tame dirvožemyje. P. fluorescens biotipas F yra tolerantiškas arsenui, jis buvo atskirtas nuo dirvožemio, užteršto arsenu ir \\ kitais toksiniais metalais ir charakterizuotas kaip augalų augimo aktyviklis bei arseno akumuliatorius. Tirtas šios atmainos \\ proteino profilis kartu su jautriojo $P$. fluorescens CECT 378 profiliu, kai natrio arsenatas yra ir kai jo nèra, naudojant dvie- \\ jų dimensijų poliakrilamido gelių elektroforezę (2D-PAGE). Geliai buvo analizuoti PDQuest, statistinè reikšmé patikrinta \\ su ANOVA. Atrasti 9 skirtingai išreikšti proteinai toleruojančioje atmainoje. Netoleruojančioje atmainoje buvo skirtingai \\ išreikšti 7 baltymai. Daug nuveikta identifikuojant proteinus su MALDI-TOF.
}

Reikšminiai žodžiai: arsenas, Pseudomonus fluorescens, toleravimas, proteinai, 2D-elektroforezè, rizobakterijos.

\section{ИЗМЕНЕНИЯ ПРОФИЛЯ ПРОТЕИНА, ВЫЗВАННЫЕ ТОЛЕРАНТНЫМИ К МЫШЬЯКУ И ЧУВСТВИТЕЛЬНЫМИ РАЗНОВИДНОСТЯМИ РSEUDOMONAS FLUORESCENS}

\author{
С. Шилев, А. Ф. Лопез, М. С. Прието, Э. Д. С. Пуэбла \\ Р е $з$ юм е
}

Pseudomonas fluorescens - это грамм-отрицательная, движущаяся бактерия в виде палочки. Известна ее метаболическая универсальность. Большинство разновидностей этого вида способны создавать колонии в корнях растений, способствуя росту растений в загрязненной тяжелыми металлами почве. Биотип P. fluorescens толерантен к мышьяку, ранее выделенному из почвы, зараженной мышьяком и другими токсичными металлами, и характеризуется как активатор роста растений и аккумуляции мышьяка. Нами исследовался профиль протеина этой разновидности совместно с профилем чувствительного СЕСТ 378 P. fluorescens в случае с мышьяком и с применением для электрофореза (2D-PAGE) двухдименсионного полиакриламидного геля. Гель был проанализирован в PDQuest, статистическое значение было подтверждено с помощью ANOVA. Были обнаружены 9 дифференцированно выраженных протеинов в толерантной разновидности при 1000 ppm As. B нетолерантной разновидности были дифференцированно выделены 7 протеинов. Идентификация протеинов с помощью MALDI-TOF продолжается.

Ключевые слова: мышьяк, Pseudomonas fluorescens, толеранция, протеин, 2-дименсионный электрофорез, ризобактерия, обработка протеинов. 
Dr. Stefan SHILEV is a PhD in Environmental Biotechnology (Microbiology) by the University of Córdoba (Spain) with Directors Prof. Enrique D. Sancho and Prof. Manuel Benlloch. At present he is working as Head Assistant Professor at the Dept of Microbiology and Environmental Biotechnologies of Agricultural University - Plovdiv, Bulgaria, 12, Mendeleev St, 4000-Plovdiv. E-mail: stefan.shilev@au-plovdiv.bg. He has realized specializations at the Sofia University in 1998, University of Córdoba in 1999-2003, post-doc research stay on proteomics at the University of Córdoba in 2007. He is a participating scientist in COST Action 837 and 859. He has published 31 abstract for conferences, 23 full papers and 10 monographs. His research interests are in the fields of phyto-, bioremediation, bacterial proteomics and waste management.

María Sancho PRIETO obtained a degree of MSc in Biological Sciences by the University of Córdoba (Spain). At present she is working as a contracted scientist - Laboratory of Agricultural Microbiology, Dept of Microbiology, Campus of Rabanales, University of Córdoba, 14071 - Córdoba. E-mail: champi92@ hotmail.com. She has realized a research visit at Dept of Plant Morphology and Physiology, University of Antwerpen, Belgium. Her research interests are in the field of arsenic phytoremediation, characterization of bacterial and yeast strains, bacterial proteomics, valorization of by-products. She has published 7 abstracts for conferences and 6 full papers.

Dr. Almudena Fernández LÓPEZ is a PhD in Microbiology by the University of Córdoba (Spain) with director Prof. Enrique D. Sancho. At present she is working as a contracted scientist - National Center of Biotecnology, Cantoblanco, Autonomous University, Madrid. E-mail: afernandez@cnb.uam.es. She has realized a research visit at Dept of Microbiology, University of Bordeaux, France. Her research interests are in the field of phytoremediation, bacterial proteomics and plant stress responses. She has published 10 abstracts for conferences and 9 full papers.

Dr. Enrique D. SANCHO is a PhD in Microbiology. He is a Professor at Dept of Microbiology, Campus of Rabanales, C-6, University of Córdoba, 14071 - Córdoba, Spain. E-mail: edsancho@uco.es. He has realized a number of specializations. He is an expert scientist in COST Action 837 and 859. He has published 76 full papers and 23 monographs. His research interests are in the fields of phytoremediation of arsenic, characterization of bacterial and yeast strains, bacterial proteomics, valorization of by-products. 